Права людини в Україні та у зарубіжних країнах:

проблеми теорії та нормативно-правової регламентації

DOI https://doi.org/10.36059/978-966-397-210-7/161-184

Заморська Л. I.,

доктор юридичних наук, доцент,

доцент кафедри людських прав

юридичного факультету

Чернівецького національного університету

імені Юрія Федьковича,

м. Чернівці

Гураленко Н. А.,

доктор юридичних наук, доцент,

доцент кафедри людських прав

юридичного факультету

Чернівецького національного університету

імені Юрія Федьковича,

м. Чернівці

\title{
ОБМЕЖЕННЯ ПРАВ ЛЮДИНИ І ЙОГО ОСНОВОПОЛОЖНІ ПРИНЦИПИ
}

Анотація. У цій науковій роботі була здійснена спроба сформулювати розуміння поняття «обмеження людських прав» як юридичні результати діяльності компетентних державних органів, передбаченої відповідними законодавчими актами, спрямованої на досягнення поставлених цілей задля забезпечення необхідного балансу інтересів окремої людини, держави та суспільства загалом, для охорони благ $i$ цінностей, що передбачені Основним Законом країни.

«Обмеження прав людини» характеризується наявністю відповідних принципів як основоположних засад, на основі яких $i$ формуються певні обмеження. Основне місце серед них належить: законності; легітимності; ясності та визначеності; наявності мети обмеження прав людини, прописаної у Основному законі країни та міжнародно-правових актах; пропориійності; введенню обмежень прав людини, спричиненому винятковими обставинами, на тимчасовий проміжок часу тощо. 


\section{Вступ}

Весь період становлення та розвитку суспільства у взаємодії з правовою державою права та свободи людини і громадянина посідають особливе місце в розвитку будьякої демократичної країни. Забезпечення прав та свобод людини і громадянина, а також їх охорона і реалізація постає надзвичайно актуальною проблемою, особливо в теперішній час, у складних умовах всесвітнього пандемічного періоду, який, як показує практика, здійснив неабиякий вплив на встановлення обмежень прав людини і безпосередньо визначив напрям подальшого впливу на розуміння встановлених меж і заборон.

Наприклад, у ст.2 Конституції України зазначено: «Людина, іiї життя i здоров'я, честь і гідність, недоторканність і безпека визнаються в Україні найвищою соціальною цінністю», i, відповідно, ця норма визначає один із стрижневих напрямів діяльності нашої держави в умовах важкої ситуації, яка складлася в наш час [13]. У країні здійснюється активна діяльність щодо покращення чинного законодавства, вносяться зміни відповідно до міжнародних стандартів, а отже, формується система права, що відповідає демократичному суспільству.

Варто підкреслити, що у законодавстві багатьох Європейських країн, таких як Німеччина, Італія, Іспанія, Франція та інші, цій проблематиці приділяється особлива увага, їх реалізація та захист гарантуються державою шляхом закріплення дієвої системи гарантій (зокрема, як показує практика, в сфері охорони здоров'я). Власне, права і свободи особи проголошуються непорушними [5, с. 118]. Незважаючи на це, ї законодавство передбачає можливість здійснення заходів, що обмежують людські права. Безсумнівно, що в такому разі обмеження має бути передбачене в законодавстві i бути неминучим i вимушеним кроком, без здійснення якого неможливо досягнути поставленої мети, забезпечити громадський порядок, безпеку суспільства тощо в період оголошення 
всесітньої пандемії, що наразі охопила весь світ, та інші охоронювані законом блага.

Протягом значного періоду науковці намагаються віднайти оптимальний баланс між забезпеченням прав та свобод однієї людини та врахуванням інтересів усього суспільства й держави загалом. Одним із проявів втілення цієї ідеї $є$ інститут обмеження прав та свобод людини, який виступає міжгалузевим, охоплюючи норми конституційного, адміністративного, кримінального, цивільного, трудового та інших галузей права, залежно від правової ситуації, яка виникає. Він регулює відносини влади і підпорядкування, а тому для нього характерніший імперативний метод правового регулювання. Обмеження основних прав здійснюється як шляхом прямих заборон, так і вилученням тієї чи іншої правомочності зі змісту конкретного права, а також шляхом встановлення спеціального порядку реалізації такого права тощо.

Зі сказаного вище випливає, що обмеження прав та свобод людини $\epsilon$ необхідним складовим чинником забезпечення оптимального поєднання інтересів людини, суспільства та держави. Ш.Л. Монтеск'є колись зазначив, що «досвід найбільш вільних народів, які коли-небудь існували на землі, змушує визнати, що бувають випадки, коли необхідно на деякий час «накинути на свободу покривало» [17, с.87]. Своєю чергою І.Л. Петрухін наголошував на тому, що потрібно перетерпіти біль державного примусу для того, щоб вилікувати суспільну хворобу [21, с. 221-222].

\section{1. Поняття обмеження прав людини}

Науковці проявляють посилену увагу вивченню проблематики обмеження прав та свобод людини й громадянина. Так, значний внесок в дослідження зазначеної проблематики зробили такі українські та радянські вчені, як Ю.М. Тодика, П. М. Рабінович, О.Г. Кушніренко, Т.М. Слінько, Д.М. Власов, М.З. Ільясов, 
Л.С. Корж, С.В. Пчелинцев та інші. В їхніх наукових працях зазначається ряд обставин, що вимагають поглибленого дослідження, серед них визначення поняття «обмеження прав особи (індивіда)», співвідношення понять «обмеження прав людини» та «порушення прав людини», визначення меж обмежень прав людини та ін.

Аналізуючи погляди М.А. Нагорної, ми дійшли думки, що обмеження прав індивіда застосовується лише у разі, коли виникає необхідність гармонізувати розбіжні інтереси суспільства, держави, особи. При цьому такі обмеження знаходять свій вираз зазвичай у зменшенні обсягу (меж) права за умови збереження його змісту [19, с. 118].

У науковій літературі побутує і така думка, згідно 3 якою обмеження права втілюється не в зменшенні, а у звуженні його обсягу (скороченні числа випадків реальної можливості реалізації права) шляхом розширення змістовної сторони через включення певних факультативних ознак, що регламентують механізм реалізації права. Саме вони можуть стосуватися носія права, порядку реалізації права, кола правомочностей, що складають право, тощо.

М.Ф. Селівон розуміє під обмеженням права не тільки звуження його обсягу, а саме таке звуження, яке здійснюється на законних підставах [34, с. 31]. В.А. Федоров трактує обмеження прав людини : «...вимушене явище, яке спровоковане об'єктивно-суб'єктивними чинниками, зазвичай політико-правової дійсності, що ставить за мету досягнути певних цілей, і здійснюється як правовими, так і неправовими засобами і способами, кількісне та якісне зменшення (російський термін «умаление») органами влади прав і свобод людини» [39, с. 118]. Причому, використовуючи термін «умаление», вчений здійснює підміну понять, фактично ототожнюючи термін «умаление» 3 терміном «порушення», тобто «обмеження прав людини» $\epsilon$ «порушенням прав людини». Ми не цілком погоджуємося з поглядами В.А. Федорова, оскільки ці два поняття $\epsilon$ відмінними між собою. Академічний тлумачний 
словник української мови зазначає [35], що зміст терміну «обмежити» полягає в тому, щоб поставити в певні рамки, межі, визначити якими-небудь умовами, а також зробити менше, скоротити обсяг чого-небудь (в цьому разі зменшити обсяг прав і свобод особи). Термін «порушення» має більш негативну природу і застосовується тільки тоді, коли наявні факти незаконної протидії реалізації прав та свобод людиною [39, с. 27]. Ця особливість чітко і ясно визначає сутність поняття «порушення прав і свобод», а отже, i доводить абсолютну нетотожність понять «обмеження прав і свобод людини» i «порушення прав i свобод людини». Під час дослідження змісту поняття «обмеження» більш доцільним буде застосування понять «звуження», «зменшення» прав людини як синонімічних до російського терміна «умаление». Тобто поняття «обмеження прав людини» включає в себе звуження змісту або обсягу цих прав. При цьому під змістом прийнято розуміти певним чином впорядковану сукупність елементів і процесів, з яких складається предмет чи явище.

Як справедливо зазаначає О.В. Должикова, обмеження прав людини - це спричинена природними, соціальними й духовними чинниками сукупність засобів, що передбачені законодавством і визначають порядок здійснення прав i свобод людини й громадянина у виняткових, надзвичайних обставинах [6, с. 115]. Водночас обмеження слід розглядати через призму поняття «заборона», оскільки обмеження за своєю юридичною суттю дуже схоже 3 забороною, але не тотожне їй. Обмеження спрямоване не на повне «знищення» будь-яких суспільних відносин, а на утримання їх у певних, чітко визначених рамках. Крім того, якщо співставляти терміни «обмеження» та «заборона», то обмеження буде виступати наслідком заборони. Слід не виключати при цьому заперечення можливості існування часткового обмеження, оскільки заборона - це завжди певне обмеження, однак обмеження - це не завжди заборона [38, с. 225-226]. Безперечно, зазначена думка має право на існування, однак потребує додаткового дослідження. 
Права людини в Україні та у зарубіжних країнах:

проблеми теорії та нормативно-правової регламентації

На думку В.А. Карташкіна, обмеження прав і свобод людини державою забезпечує вирішення таких завдань, як: підтримання правопорядку; гарантування безпеки кожної особистості; забезпечення внутрішньої і зовнішньої безпеки суспільства і держави; покращення умов для здійснення економічної діяльності і охорони всіх форм власності; використання мінімальних державних стандартів, враховуючи загальний рівень життя; сприяння розвитку культури в країні $[11$, с. 57].

При цьому О.Ф. Черданцев у своїй праці «Тлумачення права та договору» зазначає, що обмеження слід розуміти як виняткові випадки, коли права та свободи зберігаються, але обмежується можливість їхнього здійснення на певній території, у певний точно визначений часовий проміжок або стосовно певних суб'єктів [40, с. 157]. Ми вважаємо, що наведена думка дуже вдало і найбільш точно передає особливості застосування обмежень прав в умовах виникнення надзвичайних ситуацій.

Досить вдало визначає перелік допустимого обмеження прав людини, що викликаються об'єктивними причинами існування сучасного суспільства I.Ю. Ліщина, вказуючи при цьому на такі: обмеження, які викликані рівнем соціального, економічного, культурного та духовного розвитку соціуму; обмеження, що пов'язуються з певним суб'єктом та його економічними, фізичними та іншими особливостями; обмеження, що виводяться 3 загальновідомої формули «права однієї людини не повинні обмежувати права і свободи іншої людини»; такі, що вводить держава в особі її уповноважених на те органів [15, с. 31].

Своєю чергою ст. 29 Загальної декларації прав людини 1948 р. містить трактування постійних обмежень, необхідних для існування суспільства, передбачивши, що їх може встановлювати лише держава «для забезпечення правомірних вимог моралі, суспільного порядку і загального блага» [9]. У ст. 10 Європейської конвенції про захист прав людини та основоположних свобод 1950 р. міститься схожа підстава, яка передбачає, що обмеження 
можливі лише «для забезпечення державної безпеки та територіальної цілісності» [12].

Слід урахувати і погляди В.А. Номоконова, який тлумачить поняття «обмеження прав людини» двозначно: по-перше, як повне заперечення певного права та (або) свободи, що спровоковане різноманітними об'єктивними та суб'єктивними чинниками; по-друге, як звуження обсягу можливої, дозволеної поведінки (однак, не виходячи за межі конкретного права або свободи) шляхом нормативного визначення компетентними органами певних меж (часових, просторових, суб'єктивних) такої диспозитивної поведінки [20, с. 5]. Проте ми вважаємо, що таке двояке трактування містить у собі порушення логічної послідовності: перша частина поняття повністю включає в себе другу частину, або друга частина поняття повністю підпорядковуєтьчя першій.

Отже, з вищевикладеного випливає, що під час введення обмежень прав і свобод повинні враховуватись такі вимоги: по-перше, обмеження має здійснюватись відповідно до норм права, що закріплені у законах; по-друге, такі обмеження повинні відповідати принципу законності, пропорційності, недискримінації, обгрунтованості, співмірності, доцільності; по-третє, має існувати відповідність обмежень прав людини принципам і нормам міжнародного права.

Варто звернути увагу на те, що існують різноманітні погляди стосовно співвідношення таких понять, як «обмеження прав людини» i «межі здійснення прав людини». Так, німецький науковець К. Хессе підкреслював, що обмеження прав людини $\epsilon$ встановленням меж їх здійснення, трансформацією їх 3 абсолютних у чітко окреслені, оскільки обмеження визначають зміст кожного 3 видів прав індивіда [41, с. 212]. На нашу думку, такий погляд $\epsilon$ доволі дискусійним. Більш об’єктивними $\epsilon$ погляди С.В. Пчелінцева, який у своїх наукових доробках стверджував, що «існує явний взаємний зв'язок між цими поняттями, проте, як цілком влучно підкреслює науковець, 
такі терміни мають різне змістове навантаження та значення» [26, с. 17-18], Б.С. Єбзєєв також вказував на необхідність розмежовувати такі поняття, як «межі здійснення прав та свобод» і «обмеження прав та свобод», вказуючи на те, що за своєю сутністю обмеження прав людини не тотожні встановленням меж прав і свобод [7, с. 117]. Межі реалізації права особи - це зміст і обсяг певного права, система гарантій його реалізації і охорони, наявність яких зумовлена передусім конституційним ладом. Водночас під обмеженнями прав та свобод індивіда слід розуміти «вилучення окремих прав 3 правового статусу людини i громадянина, що допускається Конституцією України та іншими нормативно-правовими актами».

Отже, дискусійним видається розмежування реалізації прав людини і питання про обмеження прав людини $\epsilon$ пов'язаними між собою складовими елементами більш загальної проблеми дотримання оптимального балансу інтересів особи, суспільства та держави.

Дослідження чинного українського законодавства свідчить, що сфера використання поняття «обмеження прав» $\epsilon$ доволі широкою і торкається різноманітних аспектів існування особи, суспільства та держави загалом, особливо в такий важкий час - світової пандемії, яка, безумовно, здійснила свій вплив на сферу застосування заходів обмеження прав людини як в Україні, так і загалом у світі (передусім це стосується сфери обмеження прав на працю та інші). Незважаючи на це, виявляється парадоксальним, що жодний нормативно-правовий акт, який передбачає певні обмеження прав людини, не дає чіткого тлумачення поняття «обмеження» [42, с. 179].

Досліджуючи проблему обмеження прав людини, потрібно відрізняти два поняття: перше - безпосереднє обмеження прав (наприклад, позбавлення особи ії̈ певного права або його частини ), друге - обмеження у реалізації прав (повна або часткова неможливість скористатись певними правами). Другий підхід до трактування 
обмежень передбачає, що усі права у повному обсязі залишаються у людини - носія прав, а лише можливість їхнього здійснення на певний проміжок часу припиняється. Такий вид обмеження може бути добровільним (людина відмовляється від здійснення права, наприклад, у справах приватного обвинувачення) або ж примусовим - застосовується залежно від зовнішніх, здебільшого непередбачуваних, обставин [36, с. 65]. Приміром, це обмеження може бути наслідком введення режиму надзвичайного стану, обставин, що не залежать як від волі окремого індивіда, так і від волі держави. Випадки встановлення такого обмеження повинні бути чітко регламентовані законодавством. На нашу думку, точнішим за змістом $\epsilon$ саме трактування обмежень як обмежень у реалізації суб'єктивних прав, оскільки навіть в умовах воєнного або надзвичайного стану відбувається не тимчасове позбавлення громадян певних прав, а лише тимчасово унеможливлюється їх використання у повному обсязі.

Продовжуючи аналізувати поняття «обмеження прав людини», слід дослідити його найсуттєвіші характерні ознаки: по-перше, обмеження являє собою певні «незручні» наслідки для реалізації певними суб'єктами своїх прав, свобод і законних інтересів, при цьому права i свободи таких фізичних і юридичних осіб обмежуються, однак у той самий час задовольняється суспільний інтерес або інтерес владного суб'єкта, що ввів ці обмеження. Подруге, обмеження за своєю природою - це звуження можливої, дозволеної поведінки (діяльності) [36, с. 67]. Наприклад, Закони України «Про правовий режим території, що зазнала радіоактивного забруднення внаслідок Чорнобильської катастрофи», «Про правовий режим надзвичайного стану», «Про захист населення від інфекційних хвороб» тощо перераховують ті види діяльності, що обмежуються 3 причини виникнення надзвичайних ситуацій техногенного та природного характеру. По-третє, обмеження прав людини, які вводяться за умови виникнення надзвичайних ситуацій, 
завжди мають визначені на законодавчому рівні межі їх реалізації, такі як: просторові - обмеження встановлюються на чітко визначеній території, яка повинна бути зазначена у відповідному прововому акті (постанові Парламенту, указі Президента, розпорядженні Кабінету Міністрів відповідної країни тощо); часові обмеження вводяться за обов'язкової умови встановлення конкретного строку дії таких обмежень, що також зазначається у рішенні суб'єкта влади. Так, Закон України «Про правовий режим надзвичайного стану» чітко окреслює строки дії обмежень, що встановлюються. Вони варіюються залежно від території дії режиму, а саме 30 та 60 днів. Також вищезазначений нормативно-правовий акт гарантує можливість продовжити дію цих обмежень до 30 днів у разі такої необхідності. Тобто загальний строк дії обмежень сягає 90 днів. Однак є певний недолік у змісті цього Закону: стаття 7 не зазначає конткретного числа разів, на який можливо продовжити срок дії режиму надзвичайного стану, а отже, і максимального строку дії обмежень прав людини, які вводяться в процесі запровадження такого режиму [23].

Це питання $є$ гострим нацей час, оскільки фактично українське законодавство передбачає необмежений строк дії обмеження прав людини, які встановлюються за умови введення режиму надзвичайного стану, що може перетворити тимчасові обмеження на повсякденний стан існування суспільства та держави загалом. По-четверте, обмеження прав людини встановлюється лише уповноваженим на це суб'єктом влади, який має відповідні повноваження, прописані в законах чи інших нормативноправових актах, 3 обов'язковим дотриманням процедури введення таких обмежень. По-п'яте, обмеження прав людини, що запроваджуються, зокрема, на підставі виникнення надзвичайної ситуації, тягнуть за собою збільшення повноважень владних органів держави, на яких покладено обов'язок усунути негативні наслідки надзвичайної ситуації. Враховуючи існування балансу, 
варто наголосити, що таке розширення компетенції державних органів відбувається шляхом звуження наявного обсягу прав, свобод та законних інтересів фізичних та юридичних осіб.

Вагомий крок в охороні прав i свобод людини i громадянина від свавільного обмеження зробив Конституційний Суд України, визначивши у Рішенні від 8 квітня 2015 р. «обмеження прав і свобод, передбачених Конституцією, має мати легітимну мету; бути спричиненим суспільною необхідністю досягнення цієї мети, пропорційним та обгрунтованим; у разі обмеження права законодавець зобов'язаний запровадити таке правове регулювання, яке дасть можливість оптимально досягти легітимної мети з мінімальним втручанням у реалізацію відповідного права і не порушувати його сутнісний зміст» [27]. Крім того, важливим кроком в цьому напряму стало прийняття Постанови КМУ № 221 від 11 березня 2020 року «Про запобігання поширенню на територї України коронавірусу COVID-19» [25].

Проведений аналіз найсуттєвіших ознак обмежень прав людини дає можливість дійти висновку, що, незважаючи на політичний режим країни, обмеження - це завжди збільшення компетенції владних суб'єктів, а також - це тимчасове обмеження можливості реалізації особами своїх прав і свобод.

Враховуючи погляди вищезазначених науковців та беручи за основу проаналізовану юридичну літературу, ми можемо доповнити трактування досліджуваного поняття, зазначивши, що обмеження - це юридичні результати діяльності компетентних державних органів, передбаченої відповідними нормативно-правовими актами (законами) та спрямованої на досягнення поставлених цілей, в процесі якої звужуються варіанти диспозитивної поведінки фізичних та юридичних осіб, дозволеної відповідними правовими нормами, шляхом встановлення меж такої поведінки, які вводяться на певний конкретно визначений часовий проміжок або на чітко окресленій території, або 
Права людини в Україні та у зарубіжних країнах:

проблеми теорії та нормативно-правової регламентації

стосовно конкретних суб'єктів, і виражається у встановленні заборон, обо'язків і відповідальності з метою забезпечення необхідного балансу інтересів окремої людини, суспільства і держави загалом, для охорони благ і цінностей, що передбачені Основним Законом країни.

\section{2. Принципи обмеження прав людини}

Обмеження прав людини грунтуються на певних основопложних, фундаментальних засадах - принципах права, які виступають основоположними ідеями, фундаментальними положеннями, які знаходять вираження в нормативно-правовому акті, мають загальну цінність, вищу імперативність і закріплюють в собі суттєві правові положення. Принципи права безпосереднім чином здійснюють вплив на весь процес підготовки законів та інших нормативно-правових актів, їх прийняття, закріплення гарантій дотримання вимог права. Вони $\epsilon$ визначальним критерієм для правотворення, правозастосування та охорони права уповноваженими державними органами. Ступінь дотримання принципів права безпосереднім чином впливає на рівень стабільності та ефективності системи права. Принципи права не виникають самі по собі, вони об'єктивно зумовлені економікою, соціальним буттям, політичним ладом суспільства, що існує в певній державі, соціальною квінтесенцією держави і права, характером існуючого політичного режиму в країні, основними засадами побудови і функціонування політичної системи певного суспільства.

Як справедливо зазначає Л.Д. Воєводін, «правові принципи - це закріплені панівним законом керівні ідеї і установки, які концентровано виражають зміст всієї правотворчої діяльності» [2, с. 115]. Для визнання тих чи інших фндументальних ідей принципами необхідно, щоб вони були закріплені в керівному законі, оскільки ідеї та установки повинні мати вищу правову форму. 
Принципи обмежень прав людини є частиною більш загальної системи правових принципів і являють собою керівні установки, положення, ідеї, зазначені в Основному законі певної держави і які законодавець повинен брати за основу під час нормативного закріплення обмежень тих чи інших прав і свобод людини.

Серед основоположних принципів обмежень прав людини в будь-якій антропоцентричній державі $\epsilon$ принцип верховенства права. Це фундаментальна правова доктрина, яка передбачає, як зазначав відомий український вчений М. Козюбра, що «принцип верховенства права має самостійне значення, яке різниться від традиційної теорії та практики принципу верховенства закону, коли право не $є$ тотожним 3 системою установлених чи санкціонованих державою загальнообов'язкових правил поведінки, іншими словами, коли має місце теоретичне та практичне диференціювання права та закону, тоді як право розглядається як соціальний феномен (коли воно трактується як явище) і безпосередньо пов'язане 3 такими фундаментальними категоріями, як справедливість, свобода, рівність та гуманізм» [14, с. 5]. Окреме дослідження верховенства права як фундаментального правового принципу, в тому числі і основного принципу обмежень прав і свобод людини, було здійснене в монографії С. Головатого «Верховенство права» [3, с. 212], на яку $\epsilon$ посилання в Доповіді Венеційської Комісії «Верховенство права». Отже, випадки та межі обмежень прав людини мають бути чітко закріплені в законах, які своєю чергою $\epsilon$ правовими, тобто відповідають принципу верховенства права, а саме $\epsilon$ зрозумілими, ясними та передбачуваними.

Основоположний принцип верховенства права тісно переплітається 3 принципом правової визначеності, який відіграє важливу роль серед усіх керівних засад обмежень прав і свобод людини. Цей принцип передбачає, що межі, способи, підстави обмежень прав людини мають бути закріплені в нормативно-правових актах, які прийняті у передбаченому законом порядку, доведені до відома 
населення шляхом оприлюднення, чітко закріплюють всі умови обмежень прав і свобод, мають гарантований механізм захисту від внесення непередбачуваних змін тощо.

В Україні врегулювання проблеми обмеження прав та свобод людини опирається на принцип недопущення будьякого обмеження прав та свобод. Зсилаючись на положення, закріплені у ст. 64 Конституції України [13], можна визначити, що права та свободи людини i громадянина, закріплені в Конституції, не можуть обмежуватись, за вийнятками, які передбачаються в Законі, а у разі прийняття нових нормативно-правових актів чи внесенні змін до діючих забороняється звужувати зміст та обсяг вже наявних прав та свобод.

Для недопущення неправового обмеження прав та свобод людини були встановлені конституційні гарантії, які знайшли своє вираження у ст. 57 Конституції України [13], в якій передбачається, що нормативно-правові акти, які закріплюють права та обов'язки громадян, у разі якщо про них не було доведено до населення шляхом, який визначається законом, $\epsilon$ недіючими. Крім того, закріплюється положення, що права та свободи людини i громадянина, гарантії їх здійснення, а також обов'язки закріплюються винятково у законах України (ст. 92) [13], та будь-які зміни до Конституції України, у разі якщо вони передбачають обмеження або скасування прав та свобод людини й громадянина, забороняються (ст. 157) [13].

Як зазначає 0.0. Подмарев [22, с. 63], до принципів обмеження прав і свобод людини і громадянина слід віднести:

1) визнання людини, їі прав і свобод, гідності і честі найвищою соціальною цінністю в державі. Досліджуючи сутність цього принципу, можна дійти висновку, що, базуючись на положеннях Основного Закону України, його складовими елементами $\epsilon$ : життя і здоров'я, честь i гідність, недоторканність і безпека особи. Закріплення вищеперерахованих благ попарно зумовлено високим 
ступенем їх взаємозв'язку та невіддільності одне від одного;

2) відповідність обмежень прав людини цілям, які закріплені в панівному законі. Також поширеною практикою $\epsilon$ закріплення у статтях, що передбачають окремі права та свободи, додаткових умов обмеження реалізації цих прав та свобод;

3) рівність в обмеженнях прав i свобод. Принцип рівності правового статусу особи передбачає, що кожній людині гарантується однакова сукупність прав, свобод та обов'язків, визначається для всіх однакова міра юридичної відповідальності за однакові протиправні діяння. Згідно з цим принципом обмеження прав і свобод здійснюються на основі рівного правового положення всіх осіб i дискримінувати одного індивіда, покладачаючи на нього більший тягар обмежень прав і свобод, ніж на іншого, який перебуває в тому самому положенні, забороняється;

4) заборону обмежувати права і свободи людини за ознаками соціальної, расової, національної, мовної, етнічної чи релігійної приналежності. Принцип недискримінації передбачає відсутність неправомірного відмінного відношення (в цьому разі встановлення обмежень прав людини) до осіб, які перебувають в однакових умовах чи однакового ставлення до осіб, які знаходяться в різних умовах. Оскільки дискримінація унеможливлює реалізацію прав і свобод усіма людьми на рівних підставах, то їі заборона розглядається як один із способів дотримання рівності всіх осіб. Право на захист від дискримінації $є$ одним із найсуттєвіших прав людини, важливість якого визнана міжнародною спільнотою, воно має бути забезпечене сучасними країнами;

5) встановлення правової форми нормативного закріплення обмежень прав людини. Базуючись зазвичай на позитивістському розумінні права, обмеження прав людини можуть бути встановлені: конституцією (наприклад, у Вірменії, Білорусі, Бельгії, Боснії і Герцоговині, Туреччині, Україні, Хорватії, Естонії тощо); 
законом (зокрема, в країнах Австрії, Андоррі, Болгарії, Литві, Польщі тощо) [16, с. 118]; міжнародними законодавчими актами (у Люксембурзі людські права можуть бути обмежені лише у разі наявності умов у «Європейській Конвенції про захист прав та основоположних свобод» від 1950 р.);

6) дотримання міжнародних стандартів під час встановлення обмежень прав та свобод людини. Такі документи, як «Загальна декларація прав людини» (1948р.), «Міжнародний пакт про громадянські та політичні права» (1966 р.), «Міжнародний пакт про економічні, соціальні й культурні права» (1966 р.) та інші зосереджують увагу на тому, що особа не може бути обмежена у реалізації своїх прав та свобод. Проте, як зазначається у вже наявних міжнародних угодах, «існують чітко визначені випадки надзвичайного чи нетипового характеру, за настання яких з обов'язковим встановленням конкретних часових і просторових меж запроваджуюються обмеження прав людини» [1, с. 18]. Цілі цих можливих відступів від наявних прав і свобод захищаються міжнародними угодами. 3 одного боку, це дає можливість державі, керуючись відповідними міжнародно-правовими актами, вводити вимушені обмеження на реалізацію певних прав, а з іншого - гарантує захист громадян від свавілля держави в обмеженні їх прав.

В.В. Назаров до принципів обмежень основних прав i свобод відносить такі:

1) законність. Обмеження прав і свобод людини здійснюється згідно з законом. При цьому в законі повинні бути чітко прописані способи та механізм обмеження прав людини;

2) легітимність. Єдиною основою обмеження прав людини є визнання його суспільної необхідності, коли інші наявні засоби державного впливу $є$ недієвими, за умови існування гострої потреби встановлення меж реалізацї суб'єктивного права для захисту інтересів інших осіб, суспільства загалом; 
3) ясність, чіткість і визначеність. Закріплений у законі процесуальний порядок обмеження прав людини повинний бути прописаний таким чином, щоб він був зрозумілий як посадовій особі, так і пересічному громадянину;

4) наявність цілі обмеження прав людини, прописаної у панівному законі країни та (або) міжнародно-правових актах;

5) пропорційність. Обмеження не може бути більш жорстким, ніж цього вимагає суспільна необхідність; має бути забезпечений баланс між правами людини, гарантованими Конституцією України, і інтересами суспільства;

6) введення обмежень прав людини, що спричинене винятковими обставинами, на тимчасовий проміжок часу [18, с. 413-414].

Загальноприйнятою $\epsilon$ вимога про те, що заходи обмежувального характеру не мають бути надмірними і повинні бути відповідними обставинам, які спричинили їхнє виникнення, і в цьому разі принцип пропорційності обмеження прав і свобод $є$ одним із найсуттєвіших.

Як вважає В.Б. Рушайло, принцип пропорційності знаходить своє вираження таким чином: відповідність міри і обсягу обмежень прав і свобод людини ситуації надзвичайного або нетипового характеру; встановлення обмежень прав і свобод людини як вимушеного заходу тільки в тому разі, коли вичерпані усі заходи державного примусу, що застосовуються за звичайних обставин; визначення як мети встановлення обмежень прав і свобод людини стабілізацію або ліквідацію конкретної екстремальної ситуації.

До принципу пропорційності входять чотири основні вимоги, пов'язані головним чином 3 цілями обмежень: обгрунтування обмежень; важливість цілей обмеження; відповідність ступеня обмеження прав суспільній значимості цілей обмеження або значущості охоронюваних 
прав; необхідність застосування принципу пропорційності одночасно 3 принципами недискримінації, рівності, законності, справедливості [33, с. 217].

Аналізуючи Європейську конвенцію про захист прав та основоположних свобод 1950 р. та практику Європейського суду 3 прав людини, науковець В.А. Туманов [37, с. 34] виділяє основні принципи (критерії) правомірного обмеження прав людини:

1) обмеження прав i свобод людини мають бути передбачені законом. При цьому Європейський суд з прав людини розуміє закон в сенсі, що включає в себе будь-який нормативний акт державного органу (наприклад, «Справа Санді Таймс» проти Сполученого Королівства Великобританії (1979 р. [28]);

2) законність мети. Держава може здійснювати обмежувальні заходи задля цілей, зазначених у Конвенції (наприклад, «Справи Хендісайд проти Сполученого Королівства Великобританії» (1976 р.) [29], «Даджен проти Сполученого Королівства Великобританії» (1984р.) [30], «Мюллер та інші проти Швейцарії» (1988 р.) [31];

3) необхідність встановлення таких обмежень. Очевидна невизначеність цього критерію зумовила активну діяльність Суду з тлумачення вказаних термінів. У судових рішеннях по «Справах Хендісайд проти Сполученого Королівства Великобританії» (1976 р.), «Сілвер та інші проти Сполученого Королівства Великобританії» (1983р.) [32] було надане таке визначення «необхідності»: «воно не $\epsilon$ синонімом прикметника «необхідний»» і не має тієї гнучкості, які мають такі терміни, як «допустимий, звичайний, корисний, розумний або бажаний».

Ще в римському праві були закріплені обмеження реалізації права власності на земельні ділянки. Так, у Дігестах Юстиніана право власності на публічні дороги обмежувалося правом всіх громадян пересуватися ними, переміщувати вантажі та переганяти худобу. Власники приватних доріг також у певних випадках були зобов'язані надавати їх «для всіх і кожного» [4, с. 93]. 
Згідно 3 українським законодавством обмеженням права на землю слід вважати закріплену в законі заборону або додатковий обов'язок щодо вчинення дій, пов'язаних 3 набуттям, використанням та відчуженням земельних ділянок. Прикладом встановленого законом обмеження прав на землю $\epsilon$ заборона набуття іноземцями у власність земельних ділянок сільськогосподарського призначення. Крім цього, обмеження прав власників землі може передбачатись договором та судовим рішенням у рамках закону [10].

Дослідивши трактування поняття «обмеження прав людини» в науковій літературі, можна узагальнити такі принципи i положення, якими мають керуватись уповноважені органи під час здійснення правообмежуючих заходів: 1) справедливе співвідношення інтересів однієї людини 3 інтересами групи людей, суспільства; 2) існування балансу приватних та публічних інтересів. Необхідність поєднання приватного і публічного інтересів спонукає до обов'язкового встановлення оптимальних меж або кордонів, дотримання пріоритету принципу справедливості і недопустимості протиставлення публічних і приватних інтересів один одному. Надання переваги одному інтересу і прояв зневаги до іншого не дозволяється, оскільки публічне право ставить за мету захищати інтереси окремої людини шляхом охорони суспільства загалом. Під час зіставлення публічного і приватного інтересу реалізація інтересів суспільства може існувати лише на підставі реалізації інтересів індивіда, що забезпечується створенням на законодавчому рівні максимальних гарантій для громадян, які не допускають можливість зловживання правами людини.

Отже, проаналізувавши проблему співвідношення публічного і приватного інтересів, можна дійти висновку, що інтереси мають реалізовуватись на засадах паритету, рівноцінності, оскільки приватний інтерес не може бути забезпечений у разі порушення публічного правопорядку, а публічний інтерес втрачає своє призначення, якщо він не націлений на забезпечення реалізації приватного. 3 цього 
своєю чергою випливає, що приватне і публічне право, кожне 3 яких захищає відповідні інтереси, $€$ тісно взаємопов'язаними і невіддільними складовими частинами єдиної інтегрованої системи права; відповідність заходів, здійснених для обмеження прав людини, правомірній i нагальній меті; пріорітет обмежень прав людини, встановлених міжнародними нормативно-правовими актами, щодо обмежень, передбачених національним законодавством; неприйнятність встановлення у законах таких меж прав людини, які є вужчими, ніж ті межі, які закріплені в панівному законі держави; відсутність дискримінації (забезпечення формальної рівності) індивідів в їхніх правах і обмеженнях цих прав; законність та аргументованість необхідності обмежень прав людини.

\section{Висновки}

Таким чином, принципи обмеження прав людини - це фундаментальні, керівні положення та установки, які законодавець повинен використовувати як орієнтир під час нормативного закріплення обмежень тих чи інших прав i свобод людини. Закріплення принципів правообмеження має не тільки велике теоретичне, але й практичне значення. Оскільки вищезазначені фундаментальні положення виступають критерієм правомірності обмеження прав людини у правотворенні та правозастосуванні. Нехтування вказаними принципами призводить і до порушення передбачених законом меж здійснення прав людини.

\section{Список використаних джерел:}

1. Алексеева Л.Л., Андриченко Л.В., Боголюбов С.А., Домрин А.Н., Касаткина Н.М. Конституционное право государств Европы : Учеб. пособие для студ. юрид. вузов и $\phi$-тов / Институт законодательства и сравнительного правоведения при Правительстве Российской Федерации Москва : Волтерс Клувер, 2005. 310 с. 
2. Воеводин Л.Д. Юридический статус личности в России. Москва, 1997. 299 с.

3. Головатий С. Верховенство права. Київ : Видавництво «Фенікс», 2006, 1747 с.

4. Гринько С.Д. Дигести Юстиніана як джерело римського приватного права. Університетські наукові записки. 2007. № 1. С. 90-96.

5. Донеллі, Дж. Людські права у міжнародній політиці [Текст] : наук. вид. / пер. 3 англ. Т. Завалія. Львів : Кальварія, 2004. 280 с.

6. Должиков A.В. Конституционные критерии допустимости ограничения основных прав человека и гражданина в Российской Федерации. Тюмень, 2003. 242 с.

7. Эбзеев Б.С. Человек, народ, государство в конституционном строе Российской Федерации. Москва, 2005. $326 \mathrm{c}$.

8. Загальна декларація прав людини: ООН; Декларація, Міжнародний документ від 10.12.1948. URL: http://zakon4.rada.gov.ua/laws/show/995_015.

9. Загальна теорія держави і права (основні поняття, категорії, прав. конструкції та наук. концепції) Київ : Юрінком Інтер, 2008. 400 с.

10. Земельний Кодекс України. Редакція від 28.09.2017. URL: http://zakon3.rada.gov.ua/laws/show/2768-14.

11. Карташкин В.А. Права человека в международном праве и внутригосударственном праве. Москва : Изд-во ИГиПРАН, 1995.133 с.

12. Конвенція про захист прав людини i основоположних свобод. Ратифіковано Законом № 475/97-ВР від 17.07.97\}. URL: http://zakon0.rada.gov.ua/ laws/show/995_004.

13. Конституція України від 28 червня 1996 р (зі змінами та доповненнями станом на 20.04.2020). URL: http://zakon2.rada.gov.ua/laws/show254к/96-вр.

14. Козюбра М.І. Право і людина: лінії взаємозв'язків та тенденції розвитку.Наукові записки НаУКМА. Юридичні 
науки. 2015. T. 168. C. 3-9. URL: http://nbuv.gov.ua/UJRN/ NaUKMAun_2015_168_3.

15. Ліщина I. Регулювання реалізації рішень Європейського Суду з прав людини. Право України. 2001. № 5. C. $29-37$

16. Маклаков В.В. Современные зарубежные конституции. Москва : МЮИ, 1992. 290 с.

17. Мироненко О.М. Монтеск'є Шарль Луї. Політична енциклопедія. Редкол.: Ю. Левенець (голова), Ю. Шаповал (заст. голови) та ін. Київ : Парламентське видавництво, 2011. 465 c.

18. Назаров В.В. Обеспечение права на свободу и личную неприкосновенность в уголовном производстве. Актуальные проблемы уголовногоправа, процесса $u$ криминалистики : материалы IV междунар. наук-практ. конф., присвяч. 95-летию со дня рождения профессора М В. Салтевського (м. Одесса, 2 нояб. 2012 г.). Одесса : Феникс 2012. С. 413-417.

19. Нагорная М.A. Принципы ограничений прав человека в публичном праве. Теория и практика ограничения прав человека по российскому законодательству и международному праву : сб. науч. тр. Н. Новгород, 1998. С. 57-69.

20. Номоконов В.А. Права человека и национальная безопасность / В. А. Номоконов. Криминологический журнал Байкальского государственного университета экономики и права. Иркутск : Изд-во БГУЭП, 2008. № 2. С. 5-6.

21. Петрухин И.Л. Теоретические основы эффективности правосудия. Москва, 1979. 392 с.

22. Подмарев А.А. Ограничение прав и свобод человека и гражданина: конституционные основы и правовые позиции Конституционного Суда России. Вестник СанктПетербургского университета МВД России. 2016. № 4. C. 62-66.

23. Про правовий режим надзвичайного стану. Закон України. Редакція від 28.12.2015. URL: http://zakon3.rada.gov.ua/laws/main/1550-14. 
24. Про введення надзвичайного стану в населених пунктах Автономної Республіки Крим. Закон України. Редакція від 30.12.2005. URL: http://zakon2.rada.gov.ua/ laws/show/1692/2005.

25. Про запобігання поширенню на території України коронавірусу COVID-19. Постанова КМУ № 221 від 11 березня 2020 року. URL: https://www.kmu.gov.ua/npas/ pro-zapobigannya-poshim110320rennyu-na-teritoriyiukrayini-koronavirusu-covid-19.

26. Пчелинцев С.В. Проблемы ограничения прав и свобод граждан в условиях особых правовых режимов. Москва : НОРМА, 2006. 480 с.

27. Рішення Конституційного Суду України у справі за конституційним поданням Уповноваженого Верховної Ради України з прав людини щодо відповідності Конституції України (конституційності) положень частини другої статті 1712 Кодексу адміністративного судочинства України від 8 квітня 2015 року № 3-рп/2015. URL: http://zakon4.rada.gov.ua/laws/show/v003p710-15).

28. Рішення Європейського суду по справі «Санді Таймс» (Sunday Times) проти Об'єднаного Королівства (стаття 50)». URL: http://zakon2.rada.gov.ua/laws/show/ 980_164

29. Рішення Європейського суду по справі «Хендісайд проти Сполученого Королівства». URL: http://www.echr.coe.int/echr.

30. Рішення Європейського суду по справі «Даджен проти Сполученого королівства Великобританії та Північної Ірландії». URL: http://www.echr.coe.int/echr.

31. Рішення Європейського суду по справі «Мюллер та інші проти Швейцарії». URL: http://www.echr.coe.int/echr.

32. Рішення Європейського суду по справі «Сільвер проти Сполученого Королівства». URL: http://www.echr.coe.int/echr.

33. Рушайло В.Б. Специальные административноправовые режимы в Российской Федерации. Москва, EKCMO, 2004. $347 \mathrm{c}$. 
34. Селивон Н. Критерии ограничения прав человека в практике конституционного правосудия. Конституционное правосудие. Вестник Конференции органов конституционного контроля стран молодой демократии. 2005. Вып. 3 (29). С. 28-37.

35. Словник української мови. Академічний тлумачний словник. URL: http://sum.in.ua/s/kryterij.

36. Стефанчук М.0. Межі здійснення суб'єктивних цивільних прав. Київ, 2006. 176 с.

37. Туманов В.А. Европейский суд по правам человека. Москва, 2001. 149 с.

38. Фаткуллин Ф.Н. Проблемы теории государства и права : курс лекцій. Казань : Изд-во Казанского гос. ун-та, 1987. $336 \mathrm{c}$.

39. Федоров В.А. Правовой институт исключительного (военного и чрезвычайного) положения в Российской Федерации. Москва, 2003. 231 с.

40. Черданцев А.Ф. Толкование права и договора. Москва : ЮНИТИ, 2003. 381 с.

41. Хессе К. Основы конституционного права ФРГ. Москва, 1981. 332 с.

42. Шишкін B.I. До питання гармонізації законодавства України 3 європейським правом щодо захисту прав людини. Матер. наук.-практ. конфер. [«Проблеми гармонізації законодавства України 3 міжнародним правом»]. Київ : Інститут законодавства Верховної Ради України, 1998. С. 178-182. 